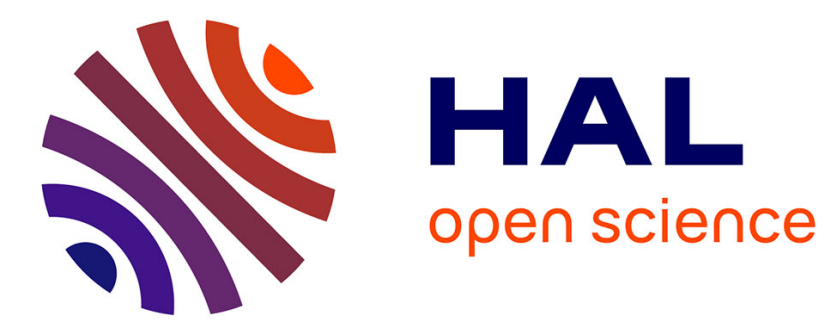

\title{
X-RAY MICROSCOPY OF BIOLOGICAL SPECIMENS
}

\author{
G. Schmahl, D. Rudolph, B. Niemann
}

\section{To cite this version:}

G. Schmahl, D. Rudolph, B. Niemann. X-RAY MICROSCOPY OF BIOLOGICAL SPECIMENS. Journal de Physique Colloques, 1978, 39 (C4), pp.C4-202-C4-204. 10.1051/jphyscol:1978423 . jpa00217457

\section{HAL Id: jpa-00217457 https://hal.science/jpa-00217457}

Submitted on 1 Jan 1978

HAL is a multi-disciplinary open access archive for the deposit and dissemination of scientific research documents, whether they are published or not. The documents may come from teaching and research institutions in France or abroad, or from public or private research centers.
L'archive ouverte pluridisciplinaire HAL, est destinée au dépôt et à la diffusion de documents scientifiques de niveau recherche, publiés ou non, émanant des établissements d'enseignement et de recherche français ou étrangers, des laboratoires publics ou privés. 


\title{
X-RAY MICROSCOPY OF BIOLOGICAL SPECIMENS
}

\author{
G. SCHMAHL, D. RUDOLPH and B. NIEMANN \\ Universitäts-Sternwarte, 34 Göttingen, \\ Geismarlandstrasse 11, R.F.A.
}

\begin{abstract}
Résumé. - Cette revue est consacrée à l'étude de specimens biologiques, poursuivie à l'aide d'un microscope à rayons-X utilisant les propriétés des zones de Fresnel et du rayonnement synchrotron. Les autres applications ainsi que les perfectionnements sont ensuite discutés.
\end{abstract}

Abstract. - A X-ray microscope using zone plates and synchrotron radiation is described. Results of biological specimens are given. Further possibilities and improvements are discussed.

Since the discovery of X-radiation by Röntgen attempts have been made to use X-radiation for microscopic work. The investigation of microscopic specimens with soft X-rays can be done in three different ways :

1) X-ray microscopy with imaging optics.

2) Scanning $X$-ray microscopy.

3) X-ray microradiography, especially using lithographic recording material.

The last point has been discussed extensively, e.g. during this conference $[1,2]$. Different types of scanning X-ray microscopes have been proposed [3, 4], however, they show either low throughput or low resolution.

There are different possibilities to realize optical elements for X-ray microscopes. Wolter [5] proposed to use two mirror grazing incidence systems, but up to now the resolution obtained with grazing incidence systems is less than that obtained with microscopes for visible light. Multilayer normal incidence reflectors are promising $[6,7]$. Up to now they have been built only for wavelengths longer than $15 \mathrm{~nm}$.

The third possibility to image soft X-rays is to use diffraction optics. Soret [8] discussed the properties of radial gratings and made experiments with zone plates using visible light. It is known that an imaging with zone plates obeys the same laws as an imaging with refractive lenses. Therefore, there had been attempts even to use low speed zone plates for soft $X$-ray imaging $[9,10]$.

Zone plates with much higher speed have been made holographically [11-15]. These zone plates with large zone numbers are realized by superposition of two coherent waves. The interference pattern is produced by using the radiation of $\mathrm{Ar}^{+}$and $\mathrm{Kr}^{+}$lasers. By subsequent preparation the interference pattern is converted into a zone plate consisting of opaque gold rings supported by a thin organic foil which is transparent to soft $\mathrm{X}$-rays.

The wavelength region between about $0.5 \mathrm{~nm}$ and $10 \mathrm{~nm}$ is suitable for X-ray microscopy. The image formation in this region is dominated by photoelectric absorption which depends critically on the used wavelength, the density and the chemical composition of the microscopic object. It is a great advantage of X-ray microscopy that biological objects, especially complete cells, can be examined directly in an aqueous environment.

It can be hoped that special cells can even be examined in a living state; furthermore, it is important that if the cells die during the X-ray exposure, nevertheless cell structures can be examined. It has already been shown theoretically, that radiation damaging in $\mathrm{X}$-ray microscopy is less severe for thick specimens than in electron microscopy [16].

It should be mentioned that only X-ray microscopy with imaging optics gives the possibility to examine different planes within a thick specimen separately, whereas with lithographic techniques one obtains only a projection of the whole object, that means integrated information of the whole thickness.

We have built a microscope for soft $\mathrm{X}$-radiation using holographically made zone plates as imaging optical elements $[17,15]$. The microscopic experiments are done using the synchrotron radiation of the Deutsches Elektronen-Synchrotron (DESY), Hamburg. Figure 1 shows the principle of the experimental arrangement. The polychromatic, slightly divergent radiation is dispersed by a holographic laminar grating used in grazing incidence. A condensor zone plate generates a reduced monochromatic image of the synchrotron source in the object plane. A magnified image of the object is generated by a micro-zone plate in the image plane. 


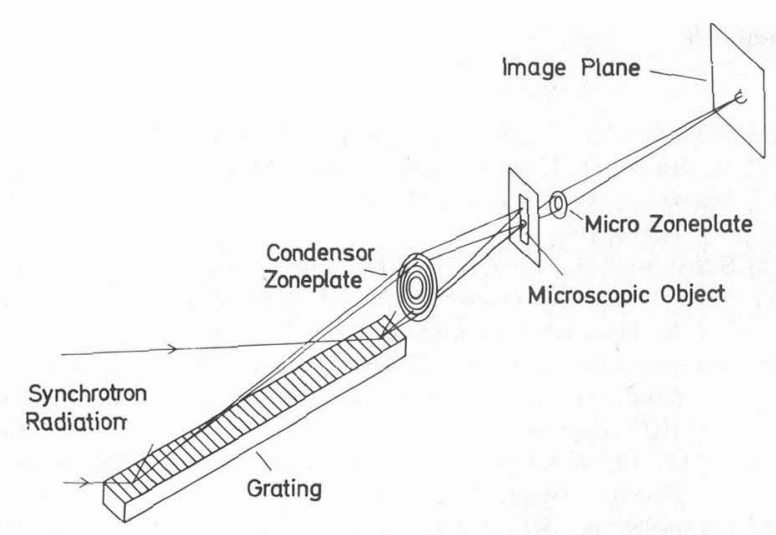

FIG. 1. - Principle of the experimental arrangement.

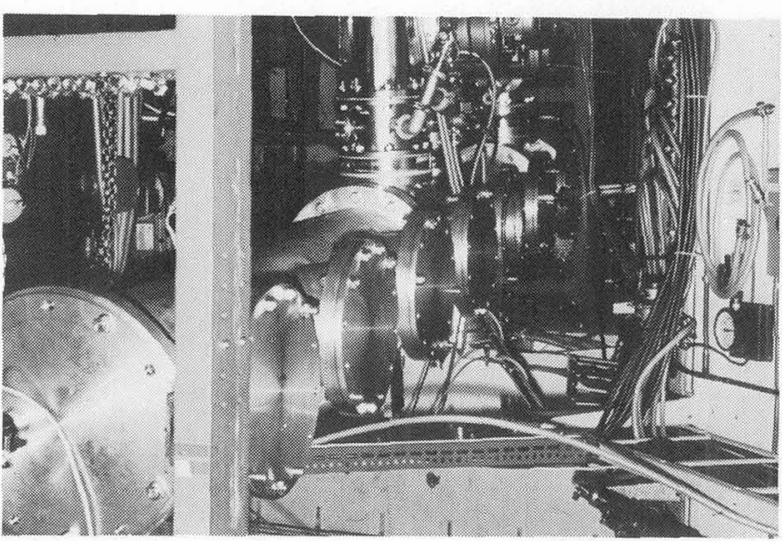

FIG. 2. - Experimental arrangement at DESY, Hamburg.

Figure 2 shows the experimental arrangement at DESY.

The use of synchrotron radiation for X-ray microscopy is advantageous because of the high intensity and the possibility to change the wavelength continuously.

By using zone plates in the first order up to now a resolution of $0.2 \mu \mathrm{m}$ has been obtained.

Microscopic images have been made of several anorganic and organic specimen, e.g. of cotton fibres, algae, He-La cells and mouse cells. Figure 3 shows as an example a mouse cell, imaged with $4.6 \mathrm{~nm}$.

A considerable improvement of the resolution is possibly by making zone plates with smaller outermost zones, by using shorter laser wavelengths and/or using the zone plates in higher orders [15]. Figure 4 shows a cotton fibre imaged in the second order and a metal grid imaged in the third order.

Up to now exposure times of several minutes were necessary. Shorter exposure times will be possible by using improved X-ray imaging elements and by using the synchrotron radiation of a storage ring.

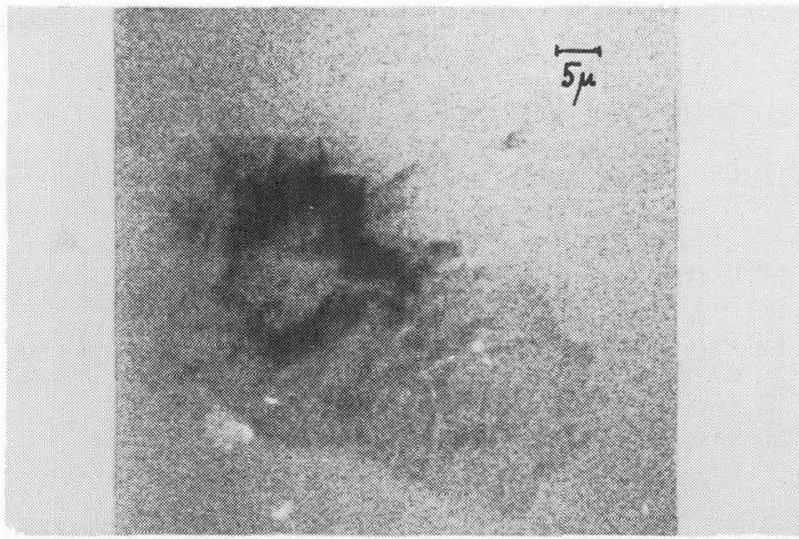

FIG. 3. -3 T3-mouse cell, $\lambda=4.6 \mathrm{~nm}, \mathrm{X}$-ray magnification $15 \times$.

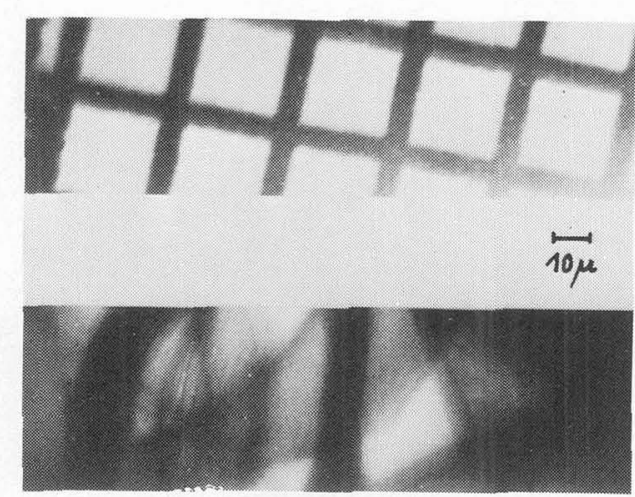

FIG. 4. - Cotton fibre, imaged with the second order of a zone plate, $\lambda=4.6 \mathrm{~nm}, \mathrm{X}$-ray magnification $25 \times$ and metal grid, imaged with the third order of a zone plate, $\lambda=4.6 \mathrm{~nm}$, X-ray magnification $15 \times$.

Up to now the efficiency of the zone plates is less than ten percent. The detective quantum efficiencies of films [18] and channelplates are in the range of ten percent. Consequently, only $1 \%$ or less of the radiation penetrating the object is recorded in the image. Possibly this can be improved by development of phase zone plates, or blazed phase zone plates or blazed Bragg-type zone plates and position sensitive detectors with high detective quantum efficiency.

A scanning X-ray microscope using zone plates and a gas counter can use for the image formation more than $50 \%$ of the radiation which is penetrating the object. This can reduce the radiation dosage by a factor $>50$ compared with the X-ray microscope which we use now.

This work was supported in part by the Deutsche Forschungsgemeinschaft and the DESY/BMFT. We are indebted to Dr. Deppert, Max-Planck-Institut ür Biophysikalische Chemie, for preparing the cells. 


\section{References}

[1] Silller, E., Feder, R., Topalian, J., J. Physique Colloq. 39 (1978) C4-205.

[2] Gudat, W., Proceedings International Conference on Synchrotron Radiation Instrumentation and Developments, Orsay 1977 , in press.

[3] Pattee, Jr., H. H., J. Opt. Soc. Am., 43 (1953) 61.

[4] Horowitz, P., Howell, J. A., Science 178 (1972) 608.

[5] Wolter, H., Ann. Phys. Lpz. 10 (1952) 94, 10 (1956) 286.

[6] Haelbich, R. P., Kunz, C., Opt. Commun. 17 (1976) 287.

[7] Spiller, E., Appl. Opt. 15 (1976) 2333.

[8] Soret, J. L., Ann. Phvs. Chem. 156 (1875) 99.

[9] v. Grote, K., Móllenstedt, G., Jönson, C., Optics and X-Ray Microanalysis (New York) 1963.

[10] EINIGHAMMER, H. J., FORSCHUNGSBERICHT, BMWF-FBW $68-27(1968)$.
[11] SchMahl, G., Rudol.PH, D., Optik 29 (1969) 577.

[12] RUDOLPH, D., FORSCHUNGSBERICHT BMFT-FBW 74-07 (1974).

[13] Niemann, B., Rudolph, D., Schmahl, G., Opt. Commun. 12 (1974) 160.

[14] SchmaHL, G., Proceedings IV. International Conference on Vacuum Ultraviolet Radiation Physics, ed. E. E. Koch, R. Haensel, C. Kunz (1974), 667.

[15] Schmahl, G., Rudolph, D., NiemanN, B., VIII. International Conference on X-Ray Optics and Microanalysis, Boston 1977 , in press.

[16] Sayre, D., Kirz, J., Feder, R., Kim, D. M., Spiller, E., Science 196 (1977) 1339.

[17] Niemann, B., Rudolph, D., Schmahl, G., Appl. Opt. 15 (1976) 1883.

[18] Niemann, B., Space Sci. Instrum. 2 (1976) 373. 